\title{
MEDIA PEMBELAJARAN E-LEARNING MENGGUNAKAN APLIKASI EDMODO PADA MASA PANDEMI
}

\author{
Musdalifa Nur ${ }^{\left.a^{*}\right)}$ \\ a) UIN Syarif Hidayatullah, Jakarta, Indonesia \\ *) e-mail korespondensi: Musdalifahnur267@gmail.com
}

\author{
Riwayat Artikel \\ diterima 29 Mei 2021 \\ direvisi 08 Juni 2021 \\ disetujui 28 Juli 2021
}

\begin{abstract}
Abstrak.
Media pembelajaran E-learning sedang marak digunakan saat masa pandemi seperti saat ini, dimana ada banyak sekali aplikasi-aplikasi/Platform yang bisa kita jadikan sebagai media pembelajaran Elearning. Salah satunya adalah Edmodo. Edmodo mampu digunakan sebagai media pembelajaran Elearning yang bisa digunakan dalam mengefektifkan proses belajar mengajar yang dilakukan secara Online saat ini. tidak hanya itu, Edmodo adalah aplikasi yang bisa digunakan dengan Samrtphone, mudah diaplikasikan bagi guru/tenag apendidik juga bagi siswa, tidak hanya itu orang tua juga mampu memantau perkembangan proses pembelajaran anak-anaknya. Pada penelitian kali ini peneliti membahas terkait 1). Tata cara penggunaana aplikasi Edmodo dalam Media pembelajaran E-learning, 2). Pemanfaatan aplikasi Edmodo dalam media Pembelajaran E-Learning. Metode yang digunakan adalah deskriptif, dengan menjelaskan secara jelas dan tepat terkait tata cara/pemakaian hingga pemanfaatan Aplikasi Edmodo dalam media Pembelajaran E-learning.
\end{abstract}

Kata Kunci: media pembelajaran E-learning; Edmodo.

\section{E-LEARNING MEDIA USING EDMODO APPLICATION DURING PANDEMIC}

\begin{abstract}
E-learning learning media is being widely used during the current pandemic, where there are lots of applications/platforms that we can use as E-learning learning media. One of them is Edmodo. Edmodo can be used as an E-learning learning media that can be used to streamline the teaching and learning process that is currently carried out online. not only that, Edmodo is an application that can be used with a smartphone, easy to apply for teachers/educators as well as for students, not only that, parents are also able to monitor the progress of their children's learning process. In this study, researchers discussed related 1). Procedures for using the Edmodo application in E-learning learning media, 2). Utilization of the Edmodo application in E-Learning Learning media. The method used is descriptive, by explaining clearly and precisely related to the procedures/usage to the use of the Edmodo Application in E-learning learning media.
\end{abstract}

Keywords: E-Learning Media; Edmodo

\section{PENDAHULUAN}

Berbicara soal kualitas pendidikan, tidak dapat dilepaskan dari proses pembelajaran di ruang kelas. Pembelajaran di ruang kelas mencakup dua aspek penting yakni guru dan siswa. Guru mempunyai tugas mengajar dan siswa belajar. Mengajar adalah mengkomunikasikan sesuatu kepada seseorang atau sekelompok orang dengan maksud agar mereka mengetahui atau mengerti apa yang diajarkan oleh guru kepadanya. Supriyono (2018) media dalam arti sempit berarti komponen bahan dan komponen alat dalam sistem pembelajaran. Dalam arti luas media berarti pemanfaatan secara maksimum semua komponen sistem dan sumber belajar di atas untuk mencapai tujuan pembelajaran tertentu. Media sarana yang disebut saluran, karena pada hakekatnya media telah memperluas dan memperpanjang kemampuan manusia untuk merasakan, mendengar dan melihat dalam batas jarak dan waktu tertentu, kini dengan bantuan media batas-batas itu hampir menjadi tidak ada. Media juga merupakan saluran komunikasi atau medium yang digunakan untuk membawa atau menyampaikan suatu pesan, di mana medium itu merupa- kan jalan atau alat dengan mana suatu pesan berjalan antara komunikator ke komunikan (Miftah, 2013)

Tuntutan perkembangan zaman membuat dunia pendidikan harus selalu dan senantiasa disesuaikan dengan perkembangan teknologi, ini salah satu upaya kita untuk meningkatkan mutu serta kualitas pendidikan. Tidak bisa kita pungkiri jika perkembangan teknologi dan informasi akan semakin pesat di era globalisasi saat ini. oleh karena itulah mengapa dikatakan bahwa teknologi informasi sangat berpengaruh kepada dunia pendidikan. Dimasa yang akan datang kita tidak akan tau faktor-faktor serta masalah apa yang akan kita hadapi contohnya saat masa pandemi seperti in. dimana apapun yang dilakukan, kita mengusahakannya dengan tanpa berinteraksi secara langsung, baik dari memenuhi kebutuhan rumah, kebutuhan kerja, bahkan proses belajar mengajar dalam dunia pendidikan dilakukan tanpa tatap muka.

Sebelumnya berbicara terkait teknologi informasi, kita ketahui bersama bahwa kemajuan ilmu dan teknologi informasi telah banyak mengubah cara pandang dan gaya hidup masyarakat Indonesia dalam menjalankan aktivitas dan kegiatannya. Keberadaan dan peranan teknologi informasi dalam sistem pendidikan telah membawa era baru 
perkembangan dunia pendidikan, tetapi perkembangan tersebut belum diimbangi dengan peningkatan sumber daya manusia yang menentukan keberhasilan dunia pendidikan di Indonesia pada umumnya. Hal ini lebih desebabkan masih tertinggalnya sumber daya manusia kita untuk memanfaatkan teknologi informasi dalam proses pendidikan tersebut (Budiman, 2017).

Dalam Budiman (2017) Christine E. Sleeter \& Peter L, yang dikutip oleh H.A.R. Tilaar, $(2012$, 55) mengatakan bahwa terdapat tiga kekuatan yang dominan yaitu Ilmu pengetahuan, Teknologi sebagai penerapan ilmu pengetahuan dan informasi.

Dunia pendidikan, kita sudah mengenal berbagai media pembelajaran berbasis IT ini mampu membantu guru/tenaga pendidik dalam proses pembelajaran, guru/tenaga pendidik mampu memberikan sentuhan-sentuhan teknologi dalam proses belajar mengajar disekolah, agar smampu menarik perhatian siswa dan membuat siswa tidak bosan dengan media pembelajran yang digunakan, ini disebut media Pembelajaran E-learning. Daryanto $(2011 ; 168)$ dalam Kamila (2016) mengungkapkan bahwa "E-Learning merupakan salah satu media pembelajaran yang dapat digunakan untuk mempermudah kinerja guru dalam mengajar. Media E-learning adalah media yang paling efisien dan dekat dengan siswa. Jika media ini dikemas dengan baik, unik dan serius maka E-learning tidak hanya sebagai media pembelajaran, tetapi juga bisa sebagai media informasi, hiburan dan pendidikan. Sekarang E-learning banyak sekali digunakan sebagai salah satu dampak Pandemi, dimana proses belajar mengajar dilaksanakan secara online

Berbicara tentang pandemi saat ini, dunia sedang dilanda Pandemi Covid-19, dimana sangat berpengaruh dari munculnya permasalahan-permasalahan pada berbagai sektor salah satunya adalah sektor pendidikan. Pandemi covid-19 menjadi kendala bagi semua kalangan di dunia dan ini juga merupakan krisis kesehatan bagi manusia. Dalam dunia pendidikan, pandemi covid 19 juga memberikan dampak yang luar biasa. Banyak sekolah di dunia ditutup untuk menghentikan penyebaran covid-19, berdasarkan laporan oleh ABC news pada tangga 7 maret 2020, puluhan negara menutup sekolah demi mencegah penyebaran virus. Seridaknya 290,5 juta peserta didik di seluruh dunia menjadi terganggu aktivitas belajarnya karena sekolah ditutup. Indonesia yang menjadi negara kedua tertinggi penyebaran covid 19 dengan lonjakan di atas 1000 . Indoensia menduduki posisi 31 dari 40 negara dengan jumlah kasus terbanyak di dunia. (Tribunnews, 2020). Berdsarkan data tersebut, hal ini menunjukkan bahwa Indonesia dalam keadaan kritis kesehatan sehingga perlu adanya solusi yang tepat untuk menghentikan penyebaran covid-19 sehingga kegiatan dapat berjalan dengan normal kembali terutama bagi dunia pendidikan (Mastura \& Santaria, 2020).

Dampak Covid-19 ini sangat besar terutama bagi dunia pendidikan, dimana ini dirasakan baik dari guru sebagai tenaga pendidik, orang tua, dan murid. Pemerintah akhirnya memutuskan bahwa pembelajaran tetap diadakan walaupun dengan jarak jauh. Disini guru/tenaga pendidik dituntut untuk menguasai berbagai macam teknologi, agar mampu dan bisa merealisasikan program pembelajaran jarak jauh, dengan memperhatikan faktor-faktor tertentu. Banyak sekali mediamedia pembelajaran yang sekarang marak digunakan oleh pendidik dan tenaga pendidik, seperti Google Classroom, Google Meet, Zoom dan lain-lain sebagainya. Salah satu media yang mungkin sudah digunakan oleh beberapa tenaga pendidik sebagai media pembelajaran jarak jauh adalah Edmodo.

Edmodo, adalah salah satu hasil dari sebuah perkembangan teknologi yang dapat membantu meningkatkan kualitas pendidikan abad 21. Dibalik semua ini terdapat perusahaan yang memberikan layanan media sosial yang bertujuan untuk mendukung sistem pembelajaran online bagi para pegiat pendidikan baik guru, siswa dosen, dan orang tua. Edmodo memungkinkan kita untuk berinteraksi dengan mudah, tentu Aplikasi ini mampu mempermudah kegiatankegiatan pembelajaran seperti memberi tugas, mengerjakan ujian, kuis dan banyak lagi. Baik dari murid, guru dan lainlain akan mendapatakan mafaat ketika penggunakan Aplikasi ini. dengan Edmodo pembelajaran akan menjadi lebih efektif,dan efesien. Oleh sebab itu, perlu kita ketahui sebagai guru/tenaga pendidik bahwa semakin pesatnya teknologi komunikasi dan informassi sekarang ditambah dengan adanya Pandemi Covid-19 yang mengharuskan kita melakukan pembelajaran secara Online, diperlukan untuk mengetahui beberapa aplikasi yang bisa kita gunakan sebagai media Pembelajaran, salah satunya adalah Edmodo. Setelah kita melihat penjelasan diatas, maka tujuan penelitian ini adalah Penggunaan dan pemanfaatan aplikasi Edmodo dalam media pembelajaran E-Learning.

penelitian terkait Aplikasi Edmodo sebagai media pembelajaran E-Learning pernah dilakukan oleh Fitriasari (2016) bahwa Edmodoo adalah sebuah platform pembelajaran sosial untuk guru/dosen dan siswa/mahasiswa yang menyediakan beberapa fitur untuk mendukung E-learning seperti pernugasan, kusi dan lain-lainnya. melalui Edmodo guru dan siswa dapat berbagi catatan dan dokumen serta dapat melanjutkan diskusi secara online. Sebagai media pembelajaran edmodo memiliki banyak kelebihan selain memiliki banyak fitur, Edmodo juga mudah digunakan bagi guru dan siswa. Selain kelebihan terdapat kekurangan yaitu pemakaian aplikasi Edmodo sangat bergantung pada koneksi internet. Penelitian selanjutnya yaitu yang dilakukan oleh Zainal,Asriyati, dan Syahrudin (2019) yaitu menghasilkan berupa media alternative pembelajran yang berupa media pembelajaran dengan menggunakan aplikasi Edmodo dengan kesimpulan bahwa setelah dites dan diadakan penilaian oleh ketiga ahli disimpulkan bahwa media pembelajaran elektronik berbasis Web menggunakan Edmodo afektif dalam meningkatkan hasil pemahaman konsep pembelajaran siswa di SMA Negeri 1 Sambas. Hal tersebut terlihat pada hasil implementasi, yang mana hasil pemahaman konspe siswa memperoleh nilai rata-rata Pre-test sebesar 6,4 sebelum penerapan/implementasi media, kemudian mengalami peningkatan menjadi 7,2 setelah Post-test hasil implementasi menggunakan Media pembelajaran elektronik yang dikembangkan. Walaupun beberapa penelitian sudah dibahas mengenai aplikasi Edmodo dalam media pembelajara E- 
learning ini, belum ditemukan adanya detail kelebihan dan kekurang yang terdapat dalam aplikasi Edmodo ini, selain itu belum pula ditemukan secara rinci yang menjelaskan bagaimana pemanfaatan aplikasi Edmodo ini dengan fiturfitur yang terdapat didalamnya, maka peneliti akan menganalsis serta mendekskripsikan hal-hal yang telah disebutkan tadi pada penelitian kali ini.

\section{METODE PENELITIAN}

Penelitian ini menggunakan Metode deskriptif, yaitu suatu bentuk penelitian yang ditunjukan untuk mendeksripsikan fenomena-fenomena yang ada baik fenomena alamiah maupun fenomena buatan manusia, ini bia berupa bentuk, aktivitas, karakteristik, perubahan, hubungan dan lain sebagainya. Pada penelitian ini peneliti akan mendeksripsikan pengoperasian aplikasi Edmodo dalam penerapan media pembelajaran E-learning, selain itu peneliti akan menjelaskan pemanfaaan baik itu kekurangan dan kelebihan serta fitur-fitur yang terdapat pada Aplikasi Edmodo dalan penerapannya sebagai media pembelajaran Elearning.

\section{HASIL DAN PEMBAHASAN}

\section{A. Pengoperasian Aplikasi Edmodo dalam Proses Pembelajaran E-learning}

Walaupun kita berbicara bahwa teknologi sudah semakin pesat dan pemanfaatannya semakin canggih pada saat sekarang ini, bukanlah ide bagus jika pendidikan sepenuhnya dialihkan keranah digital, ini karena pertimbangan beberapa faktor baik dari guru, siswa dan banyak lagi faktor penghalangnya yang menjadi pertimbangan. Namun karena adanya Virus Covid-19 ini, platform belajar online merupakan salah satu alternatif agar pendidikan tetap berjalan dan resiko terpapar virus bisa terhindari. Salah satu yang bisa mendukung proses pembelajaran online seperti ini adalah Edmodo.

Edmodo merupakan platform education network berbasis LSM (learning management system) yang akan menghubungkan guru, siswa bahkan orang tua dalam proses pembelajaran online. Edmodo diciptakan pada 1 September 2008 oleh 3 orang yaitu Nick Borg, Jeff O’Hara, dan Crystal Hutter. Pada aplikasi Edmodo ini, guru mampu dan bisa berbagi konten baik berupa teks atau vidio yang bisa dijadikan sebagai materi dikelas, dan juga bisa membagikan tugas serta kuis melalui platform Edmodo ini. Selain itu, Edmodo sebenarnya dirancang untuk kebutuhan guru agar mempermudah dimana guru mampu membuat kelas online, dan siswa dan juga orang tua siswa bisa bergabung dalam sebuah platform yang sama. Lalu muncul pertanyaan, Bagaimana penggunaan Aplikasi (Platform) Edmodo dalam proses pembelajaran online? Jawabannya sebagai berikut.Penulisan artikel harus dalam format bdua kolom dengan jarak antar kolom $0.85 \mathrm{~cm}(0.34 ")$. Langkah-langkah Penggunaan Aplikasi Edmodo adalah:

1. Sebelum bisa menggunakan aplikasi ini kita terlebih dahulu harus mendaftarkan diri, dimana terdapat 3 pilihan yaitu : kita sebagai guru/I'm teacher, pilihan kedua adalah kita sebagai siswa/I'm student, dan yang terakhir kita sebagai orang tua/I'm Parent. Cara mendaftarnya hampir sama, oleh karena itu saya memberikan contoh mendaftar dan menggunakan Edmodo untuk guru.

2. Selanjutnya yaitu kita harus mebuka situs www.edmodo.com ini bisa kita akses dari smartphone dan juga laptop.

3. Lalu pilih saya guru atau I'm Teacher (bisa juga memilih I'm student, dan I'm parent) seperti yang sudah saya dijelaskan sebelumnya,

4. Masukkan E-mail dan buat Password (kata sandi) yang mudah diingat, dan klik daftar/Sign Up.

5. Setelah Sign up, kemudian klin izinkan/Allow, dan isi biodata diri.

6. Kemudian klik membuat akun

7. Akan diminta untuk mengisi sekolah tempat kita mengajar. Jika sekolah yang kita tuju belum tersedia maka kita bisa membuat nama sekolah/universitas dan informasi lainnya.

8. Lalu klik "Step up My first class" untuk membuat kelas pertama.

Kita juga bisa mengakses Edmodo dengan mengunduh Aplikasi di smartphone kita. Tampilannya akan mudah dipahami, serta lebih mudah untuk dipakai. Bisa kita lihat tampilan aplikasi Edmodo pada smartphone berikut :

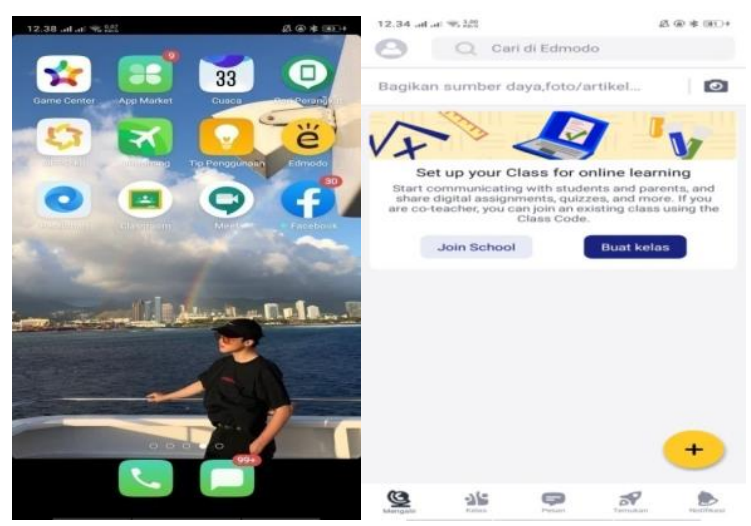

Gambar 1. Tampilan Edmodo yang telah diunduh di Smartphone

Kita bisa Join School dan membuat kelas pada halaman pertama, tidak hanya itu kita bisa membagikan materi dengan menekan tanda + pada bagian samping kanan bawah. Bisa membagikan artikel kepada siswa, dan memberikan referensireferensi lainnya agar proses pembelajaran bisa dilakukan dengan baik. Membuat kelas juga bisa kita lakukan agar proses pembelajaran lebih teratur serta terjadwal seperti pada gambar dibawah ini: 


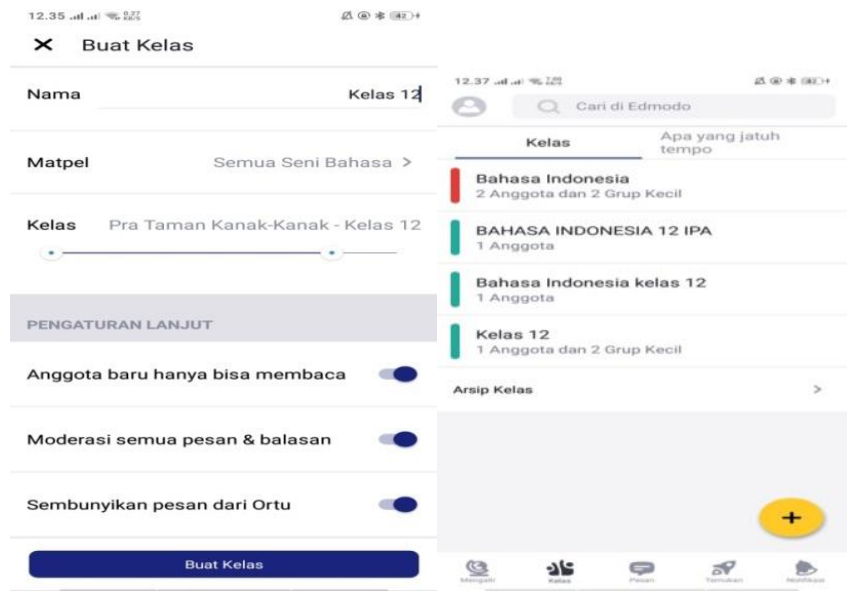

Gambar 2. Tampilan Layar pada smartphone saat membuat kelas pada aplikasi Edmodo

Pada tahap ini membuat kelas, kita perlu mengisi beberapa ketentuan seperti nama kelas, mata pelajaran, menentukan tingkatan kelas, dan mengubah peraturan dimana anggota baru bisa membaca, moderasi semua pesan dan balasan dan bisa memilih menyembunyikan pesan dari orang tua atau orang tua bisa mengakses peningkatan atau aktivitas pembelajaran anaknya. Pada fitur ini juga kita bisa menentukan jadwal tugas yang jatuh tempo serta bisa membuat arsip tugas.

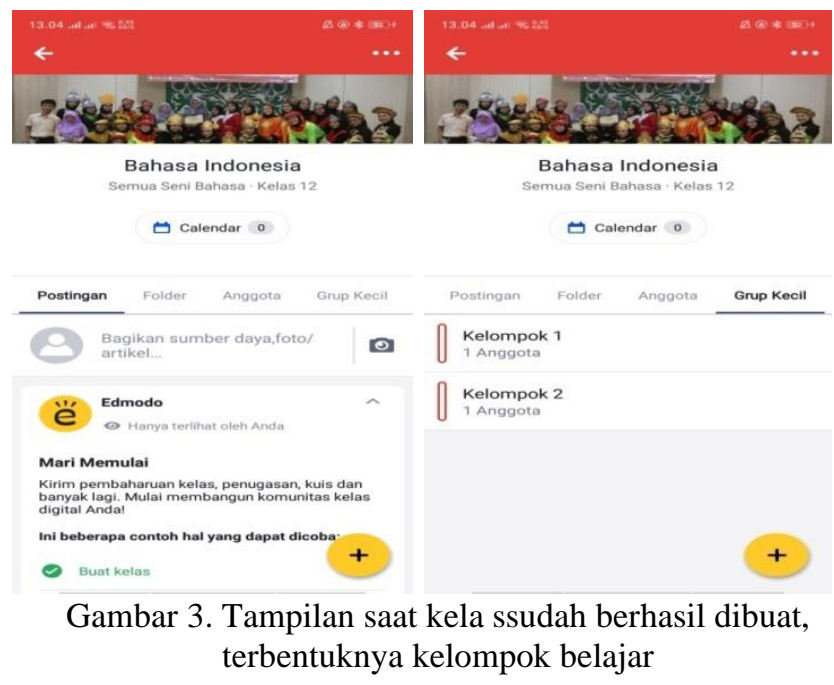

Pada kelas yang telah kita buat maka akan muncul tampilan seperti pada gambar diatas, dimana kita bisa menambahkan anggota baik dengan cara menmbahkannya sendiri, maupun membagikan link tautan dan kode kelas. Selain itu terdapat kolom folder dan group kecil, group kecil ini bisa kita bentuk untuk kelompok belajar siswa, dan kita termasuk guru bisa memantau kerja kelompok, baik itu diskusi maupun saat mengerjakan tugas. Guru juga bisa memantau bagaimana keaktifan siswa, serta bisa menghubungi siswa secara individu atau pesan pribadi jika ada tidak aktif dalam proses pembelajaran, dengan meminta penjelasan serta mengingatkan kewajiban siswa.

\section{B. Pemanfaatan Edmodo}

Pemanfaatan aplikasi Edmodo bisa dilakukan oleh guru pembelajaran apa saja, bahkan biasa digunakan pada tingkat mahasiswa sekalipun, disini akan dicontohkan bagaimana pemanfaatan aplikasi Edmodo dalam proses pembelajaran bahasa Indonesia pada tingkat SMA. Berdasarkan penjelasan pada materi sebelumnya bahwa guru dapat mengakses materi, juga bisa memberikan tugas serta kuis, bahkan bisa membuat group kecil untuk diskusi dan mengerjakan tugas perkelompok dengan memanfaatkan aplikasi Edmodo seba gai media pembelajaran. Maka berikut adalah penjabaran bagaimana pemanfaatan aplikasi Edmodo dengan mengambil contoh pembelajaran Bahasa Indonesia dengan materi Pidato.

Guru dapat mengunggah materi terlebih dahulu baik berupa power point, ataupun penjelasan dengan Vidio dan sebagainya, yang berkaitan dengan materi Pidato yang akan disampaikan kepada siswa. Sebelumnya ajak siswa untuk presensi dengan meberikan tanggapan berupa komentar dikolom pembukaan mata pelajaran yang telah guru kirimkan, seperti pada gambar berikut.

Setelah itu, agar kita bisa tahu apakah siswa paham dengan materi yang telah kita sampaikan kita bisa mengadakan sebuah tugas harian, dengan membentuk pertanyaanpertanyaan seperti meminta siswa untuk menyimak pidatopidato yang ada disosial media, mengapa kit aharus menggunakan sosial media lagi? Karena tidak memungkingkan untuk meminta siswa mengikuti sebuah pidato secara langsung karena pembelajaran berbasis online diadakan untuk mengurangi kontak secara langsung kepada orang banyak. Setelah meminta siswauntuk menyimak pidato disosial media, guru bisa mengajak siswa untuk berlatih mencatat hal-hal penting yang telah disajikan pada materi pidatoyang telah mereka simak, dan meminta siswa untuk membuat laporan berupa essai.

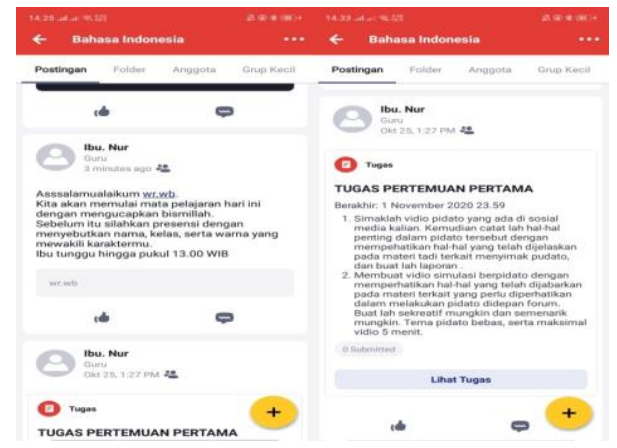

Gambar 4 : tampilan apalikasi Edmodo saat mengunggah materi belajar, memberikan tugas pada peserta didik

Pilihan lain yaitu dengan memberikan sebuah tugas untuk membuat vidio simulasi berpidato dengan memperhatikan hal-hal yang telah dijabarkan pada materi yang telah kita berikan tadi. Terkait hal-hal apa saja yang perlu kita perhatikan dalam berpidato didepan forum. Dengan meminta siswa membuat secara kreatif dan semenarik mungkin dengan maksimal vidio 5 menit. Itulah sedikit contoh pemanfaatan aplikasi Edmodo dalam proses pembelajaran bahasa Indonesia, secara online atau jarak jauh. 
Dibalik keguanaan aplikasi Edmodo ini tentu tidak luput dari kelebihan dan kekurangannya. Kelebihan aplikasi edmodo ini sendiri yaitu: memiliki tampilan yang sangat ramah dan hampir mirip seperti sosial media, sebagai platform pembelajaran aplikasi ini bisa memberikan penilaian secara langsung kepada siswa secara realtime, support dengan banyaknya jenis file yang terdapat dalam fitur Edmodo yang memungkinkan untuk membuat pembelajaran lebih menarik dimuali dari teks, gambar, vidio, kuis dan sebagainnya tergantung guru saja, bagaimana guru bisa mengkreasikan materi agar lebih tidak monoton dan bisa terlihat menarik, karena salah satu kunci pembelajaran yang aktif dan kreatif salah satunya adalah guru yang inovatif, selain itu yang menarik dan justru sangat penting dalam platform Edmodo ini, dimana orang tua bisa memantau jalannya proses pembelajaran yang dilakukan oleh siswa dan guru sehigga selain arahan serta pantauan dari guru sebagai tenaga pendidik, orang tua juga bisa memantau anaknya agar tidak menyalahi aturan pembelajaran serta bisa mengetahui kekatifan anaknya dalam proses pembelajaran. Adapun kelamahan pada aplikasi Edmodo ini adalah apalikasi akan sangat lancer dengan menggunakan desktop, sedangkan untuk versi mobile ada beberapa hal yang kadang sulirt untuk dilakukan, bahasa yang digunakan untuk mengoperasian aplikasi ini adalah bahasa inggris, sehingga akan sulit bagi siswa atau guru serta orang tua yang tidak menguasai bahasa inggris memahami pemakaiannya, terkadang aplikasi ini lambat namun jarang terjadi.

\section{SIMPULAN}

Berdasarkan yang sudah dijabarkan, kita dapat melihat bahwa penggunaan aplikasi Edmodo sebagai media pembelajaran pada saat masa pandemi seperti ini adalah suatu pilihan yang baik. Dimana Edmodo mampu memberikan fitur-fitur yang bisa dimanfaatkan oleh guru dalam mengelola materi ajaran, membuat tugas serta hal-hal yang bisa mendukung jalannya proses pembelajaran, tidak hanya itu penggunaan aplikasi ini cenderung mudah dipahami serta mampu meningkatkan kreatifitas dalam proses pembelajaran, tanpa meninggalkan suatu yang penting yaitu peran orang tua dalam proses pembelajaran sang anak juga diikutsertakan dalam fitur di Edmodo, dibalik kelebihan pasti ada kelemahannya, tetapi pihak Edmodo selalu memberikan sebuah solusi serta meningkatkan kualitas aplikasinya.

\section{REFERENSI}

Budiman, H. (2017). Peran Teknologi Informasi Dan Komunikasi Dalam Pendidikan. Al-Tadzkiyyah:
Jurnal Pendidikan Islam, 8(1), 31. https://doi.org/10.24042/atjpi.v8i1.2095

Fitriasari, P. (2016). Aplikasi Edmodo Sebagai Media Pembelajaran E-Learning. Prosiding PPs. 26 November 2016

Kamila, N. Z. (2016). Fakultas bahasa dan seni universitas negeri semarang 2015. Unnes, 145-146.

Mastura, \& Santaria, R. (2020). Dampak Pandemi Covid-19 terhadap Proses Pengajaran bagi Guru dan Siswa Pendahuluan. Jurnal Studi Guru Dan Pembelajaran, 3(2), 289-295.

Miftah, M. (2013). Fungsi, Dan Peran Media Pembelajaran Sebagai Upaya Peningkatan Kemampuan Belajar Siswa. Jurnal Kwangsan, 1(2), 95. https://doi.org/10.31800/jurnalkwangsan.v1i2.7

Supriyono. (2018). Pentingnya Media Pembelajaran Untuk Meningkatkan Minat Belajar Siswa SD. Edustream: Jurnal Pendidikan Dasar, 2(1), 43-48. https://journal.unesa.ac.id/index.php/jpd/article/view/ $6262 / 3180$

Tribunnews. (2020, Juni 14). Update Corona Indonesia 15 Juni: Bertambah 1.017 Pasien, Total 39.294 Kasus Positif, 15.123 Sembuh. Diakses dari https://www.tribunnews.com/corona/2020/06/15/upda te-corona-indonesia-15-juni-bertambah-1017-pasientotal-39294-kasus-positif-15123-sembuh

Zainal, Z., Asriyati, N., dan Syahrudin, H. (2019). Pengembangan Media Pembelajaran Elektronik Menggunakan Edmodo Dalam Meningkatkan Pemahaman Konsep Pelajaran Ekonomi. Jurnal Pendidikan dan Pembelajaran Khatulistiwa. 8(12). 